\title{
An impedance study of the adsorption of nucleic acid bases at glassy carbon electrodes
}

\author{
A.M. Oliveira-Brett* ${ }^{*}$, C.M.A. Brett, L.A. Silva \\ Departamento de Química, Universidade de Coimbra, 3004-535 Coimbra, Portugal
}

Received 1 June 2001; received in revised form 14 December 2001; accepted 17 December 2001

\begin{abstract}
Electrochemical impedance has been used to study the adsorption at glassy carbon electrodes of guanine, its corresponding nucleoside, guanosine, and adenine. Impedance studies at different concentrations and applied potentials show clearly that all three bases are adsorbed on the electrode, blocking the surface. Irradiating the electrode with low-frequency $(20 \mathrm{kHz})$ ultrasound whilst recording the impedance spectra increased transport of molecules to the electrode surface with cavitation cleaning the surface and removing strongly adsorbed molecules of bases. In this way, sonoelectrochemical experiments enabled the electrode processes to be studied in the absence of adsorption. (C) 2002 Elsevier Science B.V. All rights reserved.
\end{abstract}

Keywords: Guanine; Guanosine; Adenine; Adsorption; Electrochemical impedance; Ultrasound

\section{Introduction}

A knowledge of the detailed electrochemical behaviour of the bases which compose the DNA molecule is of fundamental importance for understanding their functions and to throw light on denaturation processes and lesions in the DNA molecule. Thus, the electrochemical study of nucleic acids and nucleic acid bases and their adsorption on different types electrode materials, namely carbon $[1,2]$ and mercury [3-6], has been of great interest.

The use of ultrasound together with electrochemistry has been evaluated in voltammetric and sonovoltammetric studies on the oxidation of thymine and cytosine at a glassy carbon electrode [3]. The principal effect of ultrasound is to increase mass transport of the analyte to the electrode and cause cavitation, which cleans surfaces, i.e. leads to removal of adsorbed products; ultrasound does not alter directly the mechanism of electrode reactions.

In this work, impedance, together with differential pulse voltammetry, has been used to study the electrochemical behaviour and adsorption at glassy carbon electrodes of guanine and its corresponding nucleoside, guanosine, and also adenine with and without applied ultrasound. This is a \footnotetext{
835295.

Corresponding author. Tel.: +351-239-835295; fax: +351-239-

E-mail address: brett@ci.uc.pt (A.M. Oliveira-Brett).
}

complement to previous studies using electrochemical impedance experiments carried out with a DNA-modified electrode [1].

\section{Experimental}

Guanine, adenine and guanosine (Sigma, $>99 \%$ purity) were used as received. Stock solutions of the bases were prepared in $0.2 \mathrm{M}$ acetate buffer at $\mathrm{pH} 4.5$ using Millipore Milli-Q ultrapure water (conductivity $<0.1 \mu \mathrm{S} \mathrm{cm}^{-1}$ ). All experiments were carried out at $25 \pm 1{ }^{\circ} \mathrm{C}$. A glassy carbon electrode (Tokai GC 20) of $3 \mathrm{~mm}$ diameter, a Pt wire counter electrode and a $\mathrm{Ag} / \mathrm{AgCl}(3.0 \mathrm{M} \mathrm{KCl})$ reference electrode, were all contained in a one-compartment $200 \mu \mathrm{l}$ volume microcell. For sonoelectrochemical experiments, a thermostated cell of capacity $20 \mathrm{~cm}^{3}$ was employed.

Electrochemical impedance measurements were carried out using a Solartron 1250 Frequency Response Analyser, coupled to a Solartron 1286 Electrochemical Interface controlled by Zplot software; fitting of the spectra was done by ZSIM CNLS software. A r.m.s. perturbation of $5 \mathrm{mV}$ was applied over the frequency range $65 \mathrm{kHz}$ to $0.01 \mathrm{~Hz}$ with five frequencies per decade. Sonoelectrochemical impedance experiments were carried out by irradiating the glassy carbon electrode with ultrasound from a Vibra cell model 501 sonic horn (Sonics and Materials) at $20 \mathrm{kHz}$ with a Ti- 
tipped probe, of $3 \mathrm{~mm}$ diameter at a distance of $6 \mathrm{~mm}$ from the glassy carbon electrode surface.

\section{Results and discussion}

Successive differential pulse voltammograms of the bases that form the DNA molecule show, already in the second potential scan, a significant decrease of the oxidation current which is attributed to blockage of the glassy carbon electrode surface [1]. Oxidation peak potentials are at 0.85 (guanine), 1.1 (guanosine) and $1.0 \mathrm{~V}$ vs. $\mathrm{Ag} / \mathrm{AgCl}$ (adenine).

Impedance spectra were recorded in order to probe this adsorption further over the potential range from 0 to $1.4 \mathrm{~V}$ vs. $\mathrm{Ag} / \mathrm{AgCl}$. For potentials less positive than those corresponding to oxidation, the impedance spectra present a pure capacitive behaviour and close to the oxidation potential a semicircle corresponding to the oxidation charge transfer reaction appeared.

To probe the adsorption effect systematically, impedance spectra at different concentrations and applied potentials were registered. Fitting of the spectra was done by using a simple equivalent circuit, composed of a $R C$ parallel combination in series with the solution resistance, $R_{\Omega}$. The resistance $R$ represents the charge transfer resistance, $R_{\mathrm{ct}}$, and the capacitance was represented by a constant phase element (CPE) in order to take into account its frequency dispersion behaviour, as normally found for solid electrodes [7]. Cell resistance values were between 30 and $35 \Omega$.

Successive impedance measurements of the DNA-bases also show increasing adsorption with time on the electrode surface, reflected in the semi-circle feature, i.e. depressed semi-circles and an increase of $R_{\mathrm{ct}}$, as exemplified in Fig. 1 for guanosine. At the same time, there is a small increase in capacitance. The irreversible adsorption of base on the glassy

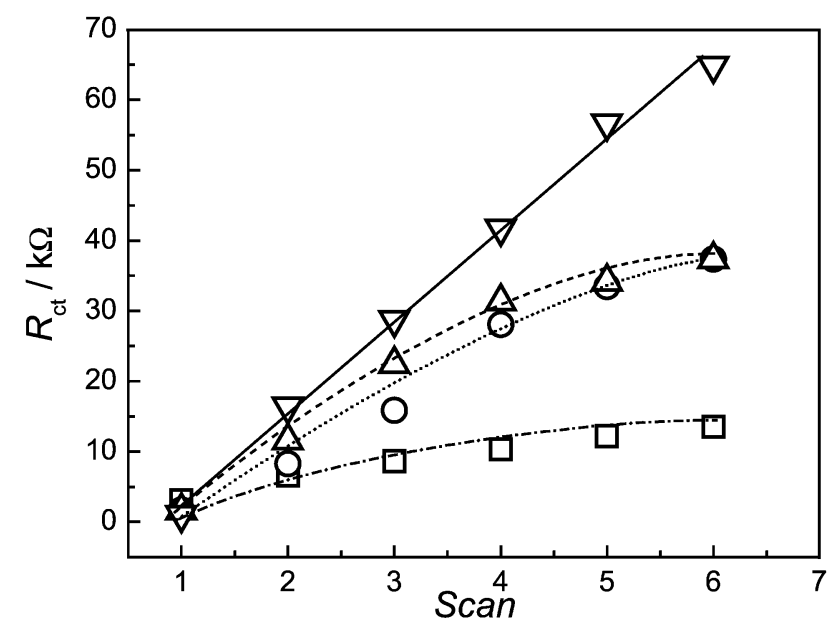

Fig. 1. Charge transfer resistance, $R_{\mathrm{ct}}$, for successive impedance measurements at $1.0 \mathrm{~V}$ vs. $\mathrm{Ag} / \mathrm{AgCl}$ at different guanosine concentrations: $(\square)$ $1 \times 10^{-3} ;(\mathrm{O}) 5 \times 10^{-3} ;(\Delta) 10 \times 10^{-3} ;(\nabla) 15 \times 10^{-3} \mathrm{M}$, in pH 4.50 .2 $\mathrm{M}$ acetate buffer.

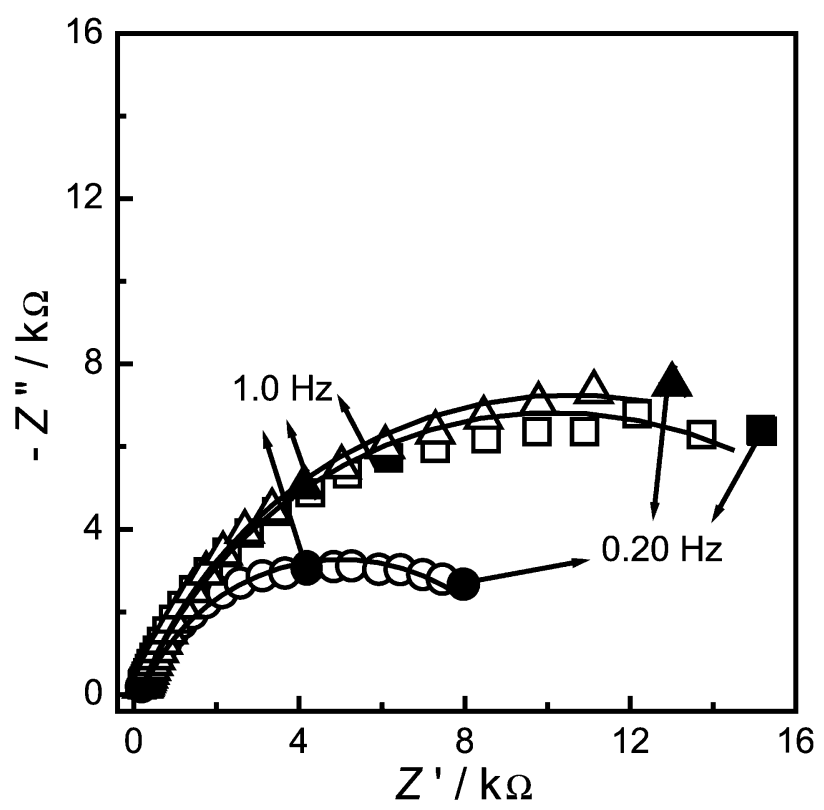

Fig. 2. Impedance spectra of $1 \times 10^{-3} \mathrm{M}$ adenine, ( $\square$ ) before ultrasound; (O) with ultrasound power $=135 \mathrm{~W} \mathrm{~cm}^{-2} ;(\Delta)$ after ultrasound at $1.1 \mathrm{~V}$ vs. $\mathrm{Ag} / \mathrm{AgCl}$ in $\mathrm{pH} 4.50 .2 \mathrm{M}$ acetate buffer. The solid lines represent curve fitting.

carbon surface is dependent on applying a potential and occurs during a timescale of minutes (each spectrum takes approximately $10 \mathrm{~min}$ to record), increasing with concentration of base.

Irradiating the zone of the electrode surface with lowfrequency $(20 \mathrm{kHz})$ ultrasound at a power density of $135 \mathrm{~W}$ $\mathrm{cm}^{-2}$ using an ultrasonic probe whilst recording the impedance spectra enables the effect of adsorption on the electron transfer process to be minimised. At potentials where charge transfer occurs, the diameter of the corresponding semicircle is constant during successive recordings so long as ultrasound is applied. The CPE and CPE exponent found under ultrasound had values of $6-18 \mu \mathrm{F}$ and $\sim 0.85$, respectively, similar to those obtained in the

Table 1

Charge transfer resistance, $R_{\mathrm{ct}}$, from impedance spectra for different concentrations of guanine, guanosine and adenine with and without ultrasound irradiation at $135 \mathrm{~W} \mathrm{~cm}^{-2}$ (oxidation potentials of the bases at which spectra were recorded are in brackets)

\begin{tabular}{|c|c|c|c|c|}
\hline $\begin{array}{l}{[\text { Base] }} \\
/ \mathrm{mM} \\
\end{array}$ & $\begin{array}{l}\text { Ultrasound } \\
\text { conditions }\end{array}$ & $\begin{array}{l}\text { Guanosine } \\
R_{\mathrm{ct}} / \mathrm{k} \Omega(1.0 \mathrm{~V})\end{array}$ & $\begin{array}{l}\text { Adenine } \\
R_{\mathrm{ct}} / \mathrm{k} \Omega(1.1 \mathrm{~V})\end{array}$ & $\begin{array}{l}\text { Guanine } R_{\mathrm{ct}} / \mathrm{k} \Omega \\
(0.85 \mathrm{~V})\end{array}$ \\
\hline \multirow[t]{3}{*}{1} & Before & 7.1 & 20.0 & 19.9 \\
\hline & $\begin{array}{l}\text { During } \\
\text { sonication }\end{array}$ & 4.9 & 9.6 & 4.2 \\
\hline & After & 8.6 & 20.9 & 16.9 \\
\hline 5 & $\begin{array}{l}\text { During } \\
\text { sonication }\end{array}$ & 6.8 & 8.9 & - \\
\hline 10 & $\begin{array}{l}\text { During } \\
\text { sonication }\end{array}$ & 6.2 & 7.3 & - \\
\hline 15 & $\begin{array}{l}\text { During } \\
\text { sonication }\end{array}$ & 5.4 & 7.2 & - \\
\hline
\end{tabular}

Measurements in $\mathrm{pH} 4.50 .2 \mathrm{M}$ acetate buffer. 
absence of ultrasound. However, the $R_{\mathrm{ct}}$ values are significantly lower than under silent conditions, and represent the true rate of the electron transfer process without complications from adsorption (Fig. 2 and Table 1). Table 1 also demonstrates, for a concentration of $1 \mathrm{mM}$ base, that the influence of adsorption is similar before and after applying ultrasound. There is some reduction in $R_{\mathrm{ct}}$ at higher base concentrations. Sequences of experiments for each of the experimental conditions were carried out four times and the difference in calculated parameters was less than $10 \%$.

Comparing the data for the different bases, it is found that under silent conditions $R_{\mathrm{ct}}$ is lowest for guanosine. However, with ultrasound and for the concentrations studied the $R_{\mathrm{ct}}$-values are similar for all three DNA bases. Consequently, the strength of adsorption of the DNA-bases on the glassy carbon surface seems to have the same intensity.

\section{Conclusion}

The adsorption process of DNA bases can be followed by electrochemical impedance measurements. On glassy carbon electrodes, the strength of adsorption appears to be similar for guanine, guanosine and adenine. Irradiation with ultrasound leads to removal of the "irreversibly" adsorbed molecules of base from the electrode surface and permits measurement of the true electron transfer rate without surface blocking.

\section{Acknowledgements}

Financial support from Fundação para a Ciência e Tecnologia (FCT) project PRAXIS/P/AGR/12205/1998, ICEMS (Research Unit 103) and European Project ERBICT15-CT-960804 are gratefully acknowledged.

\section{References}

[1] C.M.A. Brett, A.M. Oliveira Brett, S.H.P. Serrano, An EIS study of DNA-modified electrodes, Electrochim. Acta 44 (1999) 4233-4239.

[2] A.M. Oliveira Brett, F.-M. Matysik, Voltammetric and sonovoltammetric studies on the oxidation of thymine and cytosine at a glassy carbon electrode, J. Electroanal. Chem. 429 (1997) 95-99.

[3] V. Vetterl, R. Levie, The effect of halide ions on the condensation of adenine at mercury-water interface, J. Electroanal. Chem. 310 (1991) $305-315$.

[4] V. Vetterl, Alternating current polarography of nucleosides, J. Electroanal. Chem. 19 (1968) 169-173.

[5] M. Fojta, R.P. Bowater, V. Stanková, L. Havran, D.M.L. Lilley, E. Palecek, Two superhelix density-dependent DNA transitions detected by changes in DNA adsorption/desorption behavior, Biochemistry 37 (1998) 4853-4862.

[6] M. Fojta, V. Vetterl, M. Tomschik, F. Jelen, P. Nielsen, J. Wang, E. Palecek, Adsorption of peptide nucleic acid DNA decamers at electrically charged surfaces, Biophys. J. 72 (1997) 2285-2293.

[7] R. de Levie, On porous electrodes in electrolyte solutions-IV, Electrochim. Acta 9 (1964) 1231. 